\title{
CHIRAL SEPARATION BY LIGAND-EXCHANGE
}

\author{
Martin G. Schmid, Gerald Gübitz* \\ Institute of Pharmaceutical Sciences, Dept. of Pharmaceutical Chemistry, \\ Karl-Franzens-University, Universitätsplatz 1, A-8010 Graz, Austria \\ *guebitz@uni-graz.at
}

The principle of chiral ligand-exchange, introduced by Davankov, has become a widely used technique for chiral separation in both chromatography and in electromigration techniques. This simple technique makes use of the formation of mixed metal chelate complexes between a chiral selector and both enantiomers of an analyte. In HPLC, the chiral selector can be either bonded to the stationary phase or added to the mobile phase. In CE the chiral selector is simply added to the electrolyte. A relatively new approach represents CEC, where capillaries contain a chiral stationary phase. More than thousand papers appeared in the field of chiral ligand-exchange. To cite all papers would require several books.

The present article gives an overview of both milestones and our activities on chiral separation using the principle of ligand-exchange. Recent advances in chip technology for chiral separations and new approaches regarding improvement of detection sensitivity are mentioned.

Keywords: ligand-exchange; chiral selectors; chemically bonded phases; dynamically coated phases; monolithic phases; HPLC; capillary electrophoresis; capillary electrochromatography

\section{ХИРАЛНИ РАЗДВОЈУВАЊА СО ИЗМЕНА НА ЛИГАНДИ}

Принципот на измена на лиганди, воведен од Даванков, стана широко користена техника за хирални раздвојувања и во хроматографските и во електромиграциските техники. Оваа едноставна техника го користи образувањето на мешани металохелатни комплекси помеѓу хирален селектор и обата енантиомера на аналитот. Во високоефикасната течна хроматографија (HPLC) хиралниот селектор може да биде врзан на стационарната фаза или додаден во мобилната фаза. Во капиларната електрофореза (СЕ) хиралниот селектор едноставно се додава во електролитот. Капиларната електрохроматографија (CEC) претставува релативно нов пристап, каде што капиларите содржат хирална стационарна фаза. Објавени се повеќе од илјада трудови од областа на хирални раздвојувања со измена на лиганди и потребни би биле повеќе книги за сите тие да се соберат.

Во овој труд е даден преглед на главните развојни точки и на нашата работа на хирални разделувања со употреба на принципот на измена на лиганди. Освен тоа, наведени се и последните достигнувања на чип-технологијата за хирални раздвојувања и новите пристапи поврзани со подобрување на осетливоста на детекцијата.

Клучни зборови: измена на лиганди; хирални селектори; хемиски врзани фази; динамички нанесени фази; монолитни фази; HPLC; капиларна електрофореза; капиларна електрохроматографија 


\section{INTRODUCTION}

\subsection{Chiral separations}

A big number of compounds of biological or pharmacological interest are chiral. More than $60 \%$ of the drugs in use contain asymmetry centers but only about $25 \%$ are administered as pure enantiomers. However, it is well established that in most cases the pharmacological effect is restricted to only one enantiomer (eutomer) while the unwanted enantiomer (distomer) has either less activity or no activity or can exhibit even toxic effects. The most frequently cited example is thalidomide, about which we now know that only the S-enantiomer is responsible for the teratogenic effect. There are a lot of similar examples existing. Even if the side effects of the distomer are not that drastic, it has to be metabolized and represents an unnecessary burden for the organism. In fact it is a $50 \%$ impurity. Therefore, the authorities force the pharmaceutical industry to bring with new developed drugs only the pure enantiomers onto the market.

Analytical chiral separation methods based on chromatography and capillary electrophoresis have been widely developed for controlling the enantiomer purity. Moreover, chromatographic methods are in use also on a preparative scale.

Chiral ligand exchange represents a powerful chiral separation principle, used both in chromatography and electromigration techniques. Our group has been working on chiral ligand-exchange for more than 30 years. This article will give an overview of our activities in this field.

\section{SEPARATION BY LIQUID CHROMATOGRAPHY}

Pioneering work in the field of chiral ligand-exchange was done by Davankov's group who introduced this principle in the late 1960s - early 1970s [1-3].
The first phases were prepared by binding chiral amino acids to a polystyrene-divinylbenzene copolymer. The phases were packed into classical glass columns. After complexation with $\mathrm{Cu}(\mathrm{II})$ ions, these phases showed remarkable enantioselectivity, however, efficiency was low. We transferred this principle to HPLC by chemically binding amino acids to silica gel via a suitable silane [4-7] (Figure 1). Cyclic amino acids such as L-proline or L-4-hydroxyproline as chiral selectors showed the best results (Figure 2). Contrary to the hydrophobic phases of Davankov, on our rather hydrophilic phases the enantiomer elution order was D before L-A reversal of the elution order can be obtained by using a chiral selector with the opposite chirality. When D-proline was used, the elution order was L before D.<smiles>[X]C1CC(C(=O)O)N(CC(O)COCCCC(C)(C)O[Si](C)(C)C)C1</smiles>

CSPIa: $\mathrm{X}=\mathrm{H} \quad$ CSPIb: $\mathrm{X}=\mathrm{OH}$

Fig. 1. Structure of silica-based chiral ligand-exchange phases using L-proline and L-4-hydroxyproline

Reversal of the EMO is of importance in enantiomer purity checks. The enantiomer present in minor amounts should always appear as first peak to avoid of being covered by the tailing of the major peak.

The principle of chiral ligand-exchange is based on the formation of diastereomeric ternary mixed metal complexes between the enantiomerically pure selector ligand and the analyte as shown in Scheme 1. Different thermodynamics in stability of the mixed complexes between the selector and the two enantiomers are responsible for enantioseparation. A prerequisite of a successful enantioseparation is the presence of certain functional groups, such as amino-, hydroxy- or carboxy groups on both selector and analyte. 


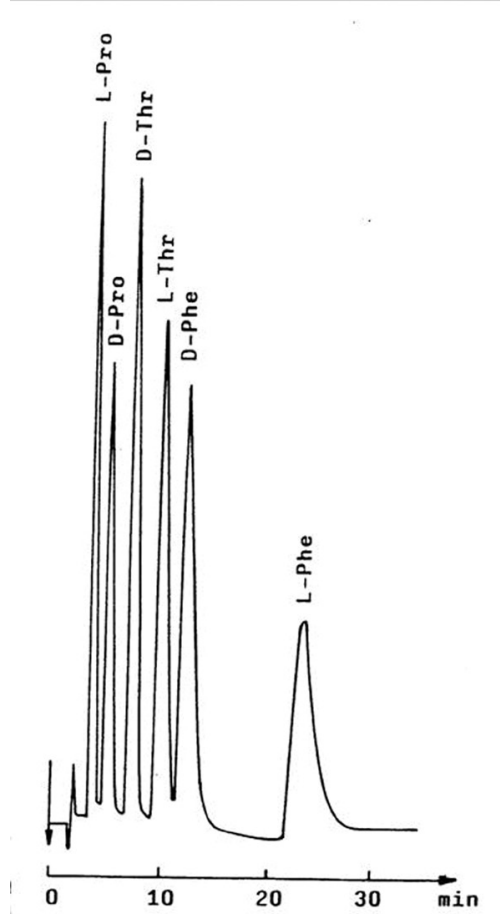

Fig. 2: Enantioseparation of a mixture of amino acids by LEC. Conditions: Mobile phase, $0.05 \mathrm{M} \mathrm{KH}_{2} \mathrm{PO}_{4}$ ( $\left.\mathrm{pH} 4.6\right)-10^{-4} \mathrm{M} \mathrm{CuSO}_{4}$; flow rate $1 \mathrm{ml} / \mathrm{min}$

In addition to underivatized amino acids, these silica based phases showed enantioselectivity for $\alpha$-alkyl amino acids [4], ß-methylamino acids [8], N-protected amino acids [4], $\alpha$-hydroxy acids [9], dipeptides [4, 10] and thyroid hormones [11]. Phases of this type have been commercialized by Daicel Chem. Ind. Ltd. (www.daicel.co.jp).

$$
\begin{gathered}
\mathrm{Cu}(\mathrm{L}-\mathrm{Sel})_{2}+\mathrm{L}-\mathrm{A} \leftrightarrows \mathrm{Cu}(\mathrm{L}-\mathrm{Sel})(\mathrm{L}-\mathrm{A})+\mathrm{L}-\mathrm{Sel} \\
\text { Sel: selector } \\
\mathrm{Cu}(\mathrm{L}-\mathrm{Sel})_{2}+\mathrm{D}-\mathrm{A} \leftrightarrows \mathrm{Cu}(\mathrm{L}-\mathrm{Sel})(\mathrm{D}-\mathrm{A})+\mathrm{L}-\mathrm{Sel} \\
\mathrm{A}: \text { analyte } \\
\text { Scheme } 1
\end{gathered}
$$

The structure of these phases has been systematically varied studying the influence of different spacers on enantioselectivity [12] (Figure 3). In addition to an improved separation power for amino acids, these phases showed chiral recognition ability for hydroxy acids, dipeptides and barbiturates. A lot of publications appeared in the following on this field [13-16].
An alternative to chemically bonded phases is the preparation of dynamically coated phases $[17,18]$. In this approach a non-chiral reversed phase column is coated with a chiral amino acid<smiles>C[Si](C)(C)O[Si](C)(C)CCC1CCC(O)C(N2CCCC2C(=O)O)C1</smiles><smiles>CCCCCCCCCC(O)CN1CCCC1C(=O)O</smiles>

Fig. 3. Chemical structure of ligand-exchange CSPs

derivative containing a hydrophobic chain. The drawback of this simple technique, however, is that the choice of mobile phase is restricted to predominantly aqueous solutions.

A recent trend for high performance separation techniques is miniaturization. We used a commercially available $3 \mu \mathrm{m}$ phenyl-octadecyl micro LC column and coated it with $\mathrm{N}$-decylL-4-hydroxyproline [19]. With this technique a series of underivatized aromatic and aliphatic amino acids were resolved (Figure 4); elution order was L before $\mathrm{D}$, what is in accordance with Davankov's coated phases.

Very rapid separations were reported by Schmid et al. [20] on a silica based monolithic RP-18 column coated with long-chain n-alkyl derivatives of L-4-hydroxyproline. These coatings were shown to be stable against desorption for months at ambient temperature when aqueous mobile phases were used. The monolithic columns were applied to the chiral separation of amino acids, glycyl dipeptides and diastereomeric dipeptides and tripeptides. These columns were easy to prepare and showed high permeability allowing high flow rates. Very fast separations in the range of seconds were achieved using flow rates of $8 \mathrm{ml} / \mathrm{min}$. (Figure 5). The chiral selector can be removed or changed easily by washing the column with an organic solvent such as acetonitrile. 


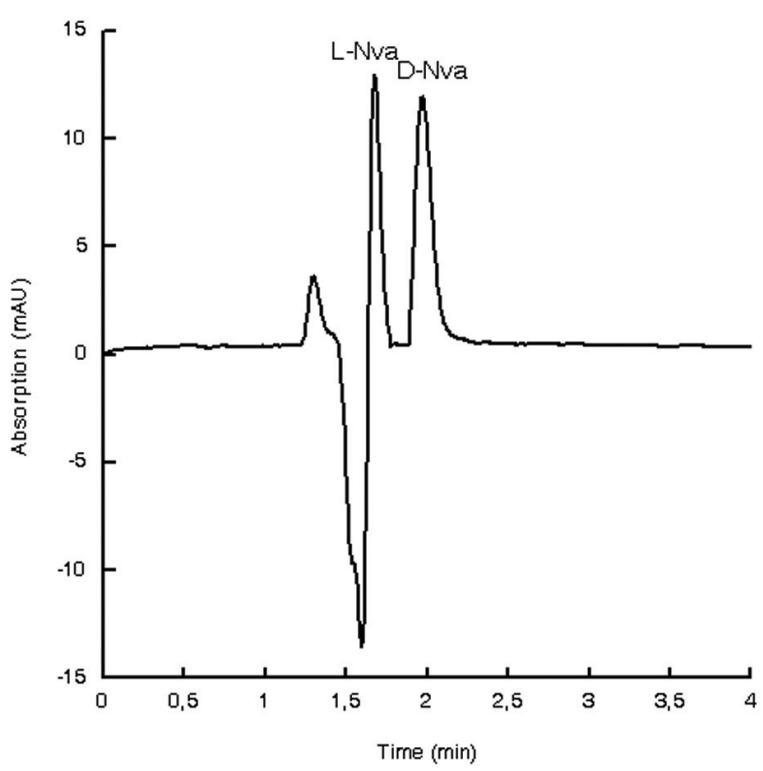

Fig. 4: Chromatogram of the enantioresolution of norvaline. Conditions: Ultimate 3000 micro-LC, ACE-C18-AR column coated with $\mathrm{N}$-decyl-L-4-hydroxyproline, 50 $\mathrm{mM}$ phosphate solution $\mathrm{pH} 4.5,1 \mathrm{mM} \mathrm{Cu}(\mathrm{II})$, injection $0.1 \mu \mathrm{l}$, flow: $50 \mu \mathrm{l} / \mathrm{min}$

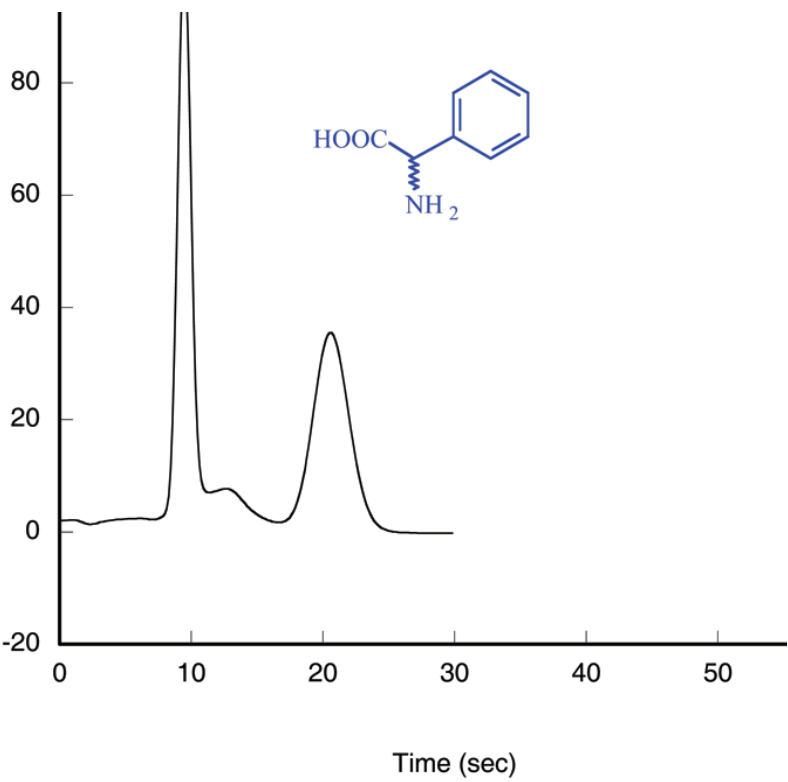

Fig. 5: Chromatogram of the rapid chiral separation of phenylglycine. Stationary phase: RP-18 monolithic column coated with $\mathrm{N}$-decyl-L-4-hydroxyproline.

Mobile phase: $0.1 \mathrm{mM} \mathrm{Cu}(\mathrm{II})$ sulfate. Injection $1 \mu$; flow: $8 \mathrm{ml} / \mathrm{min}$
A simple alternative to chiral stationary phases is the use of chiral mobile phases. This approach was applied by several authors [21, 22].

Recently, we succeeded in the chiral separation of Leu on an ODS monolithic column and L-4-hydroxyproline/ $\mathrm{Cu}$ (II) as a mobile phase additive. In this case, EEO was D before L [23]. Drawbacks of this simple technique, however, are the high consumption of chiral selectors; furthermore, this approach is not applicable to preparative separations.

\section{SEPARATION BY ELECTROMIGRATION TECHNIQUES}

\subsection{Capillary zone electrophoresis}

The principe of chiral ligand-exchange has been transferred to CE by Zare's group. They used histidine [24] and aspartame/Cu(II) complexes [25] as chiral selectors added to the electrolyte and resolved dansyl amino acids.

We demonstrated that by using simply Lproline or L-4-hydroxyproline $\mathrm{Cu}$ (II) complexes as electrolyte additives, a series of amino acids could be resolved. (Figure 6A) [26]. When an anionic surfactant such as SDS is added, following the principle of micellar electrokinetic chromatography, significant improvement of resolution and a reversal of the migration order of the amino acids according their hydrophobicity, was observed. Additionally, a reversal of the enantiomer migration order (EMO) occurred. The possibility of reversing the EMO is of importance for purity checks. A reversal of the EMO can be obtained also by changing from an L-selector to a D-selector. Furthermore, EMO is reversed when cis-L-hydroxyproline is used instead of trans-L-hydroxyproline [27].

An improvement of enantioselectivity was obtained by attaching hydroxyalkyl chains to the nitrogen of L-4-hydroxyproline [28] (Figure 7).

Besides improved enantioselectivity for amino acids these selectors showed also chiral 

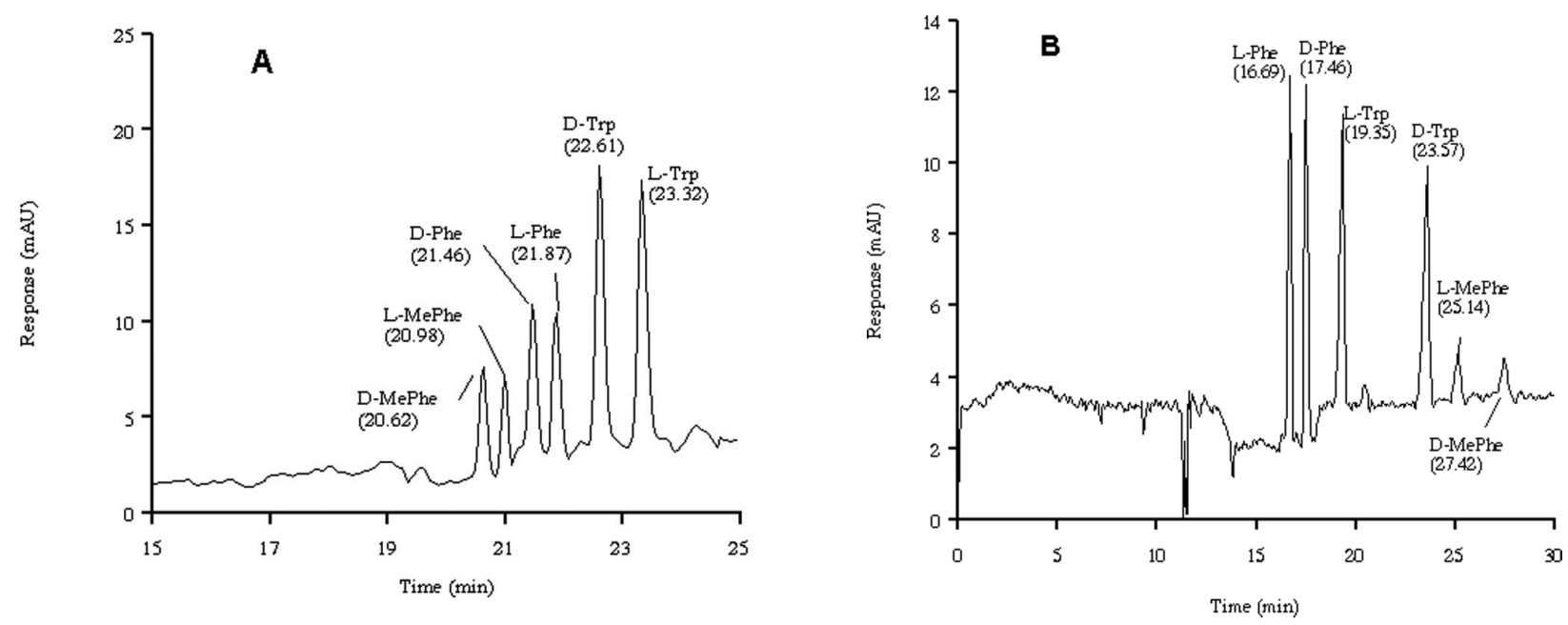

Fig. 6. Reversal of EMO: Electropherogram of the enantiomer separation of a-methylphenylalanine (MePhe), phenylalanine and tryptophan:

(A) $80 \mathrm{mM} \mathrm{L}$-4-hydroxyproline, $40 \mathrm{mM} \mathrm{Cu}^{2+}$, adjusted with $\mathrm{NH}_{3}$ to $\mathrm{pH} 4.0$;

(B) $50 \mathrm{mM} \mathrm{L}$-4-hydroxyproline, $25 \mathrm{mM} \mathrm{Cu}^{2+}, 15 \mathrm{mM}$ SDS and $3 \mathrm{M}$ urea, adjusted with $\mathrm{NH}_{3}$ to $\mathrm{pH} 4.0$ ), $\mathrm{U}=27 \mathrm{kV}$

recognition abitlity for $\beta$-methyl amino acids [8] halogenated aromatic amino acids [29] and dipeptides [30]. Furthermore, with these selectors also drugs with amino alcohol structure such as sympathomimetics and $\beta$-blockers were resolved [30, 31].
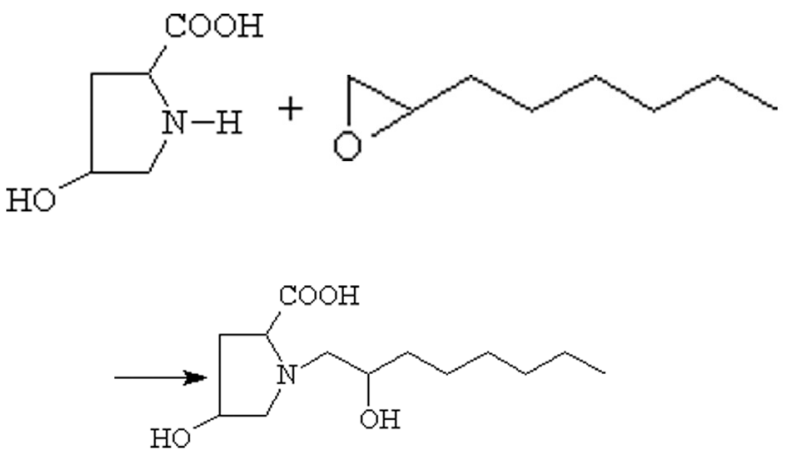

Fig. 7. Synthesis of N-(2-hydroxyoctyl)-L-4hydroxyproline

Sympathomimetics and $\beta$-blockers were resolved also with the $\mathrm{Cu}$ (II) complexes of $\mathrm{L}$ tartaric acid and L-threonine [32]. Recently the influence of different central metal ions such as $\mathrm{Cu}(\mathrm{II}), \mathrm{Co}(\mathrm{II}), \mathrm{Cd}(\mathrm{II}), \mathrm{Ni}(\mathrm{II})$ and $\mathrm{Zn}$ (II) on enantioseparation of dansylated amino acids using L-phenylalaninamide, L-lysine and L- threonine as chiral selectors was studied [33]. Figure 8 shows the chiral separation of separation of Dns-DL-Asp, Dns-DL-Met, DnsDL-Asp, Dns-DL- $\alpha-$ ABA and Dns-DL-Leu with L-lysine as chiral selector.

In the course of looking for further natural compounds as chiral selectors for LECE, we investigated sugar acids such as D-gluconic acid, D-saccharic acid and L-threonic acid by means of the enantioseparation of a series of aromatic amino acids and dipeptides. As metal ions besides $\mathrm{Cu}(\mathrm{II}), \mathrm{Co}(\mathrm{II}), \mathrm{Ni}(\mathrm{II})$ and $\mathrm{Zn}$ (II) were checked [34]. While in most of the cases $\mathrm{Cu}$ (II) was found to be the most effective complexing ion, with D-gluconic acid $\mathrm{Co}$ (II) turned out to be optimal for the enantioseparation of amino acids. With Ni(II) only partial separations were obtained and $\mathrm{Zn}$ (II) gave no results.

An approach related to ligand exchange is the formation of mixed borate-diol complexes. We studied different cyclodextrins in the presence of borate: A dual chiral recognition mechanism is assumed to take place: Inclusion of the aromatic moiety of the analyte into the cavity of the cyclodextrin and the formation of a mixed borate complex involving 


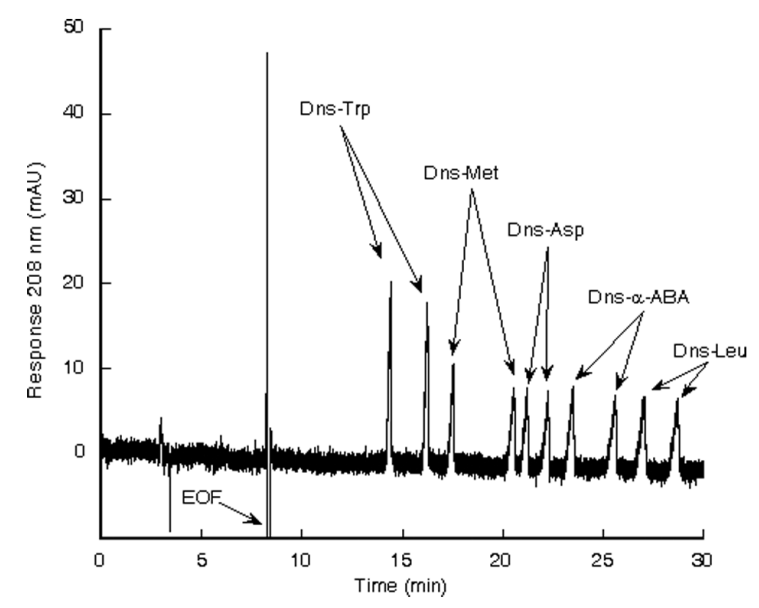

Fig. 8. Simultaneous chiral separation of Dns-DLAsp, Dns-DL-Met, Dns-DL-Asp, Dns-DL-a-ABA and Dns-DL-Leu with L-lysine as chiral selector. Conditions: $10 \mathrm{mM}$ L-lysine, $5 \mathrm{mM}$ copper(II) sulfate, $25 \mathrm{mM}$ ammonium acetate, adjusted with ammonia to pH 5.5; applied voltage: $27 \mathrm{kV}$ to cathode. Injection: 10 mbar for $5 \mathrm{~s}$

the hydroxyl groups at the $\mathrm{C}-2$ and the $\mathrm{C}-3$ at the mouth of the CD and the hydroxyls of the 1,2-diol of the analyte.

This assumption is proven by the fact that no separation occurred when $\beta-C D$ was replaced by 2,6 -dimethyl- $\beta-C D$ and $2,3,6$-trimethyl- $\beta-C D$. This technique was applied to various diols, hydrobenzoin [35] and some quinazolines containing 1,2-diol side chains [36].

\subsection{Capillary electrochromatography (CEC)}

CEC can be regarded as a hybrid technique between HPLC and CE, combining the efficiency of CE and the selectivity of chromatographic stationary phases.

Three variations are possible in chiral CEC: The use of open-tubular containing the chiral selector coated to the capillary wall, the use of capillaries packed with silica based chiral phase and monolithic phases.

We compared capillaries packed with a $3 \mu \mathrm{m}$ silica based chemically bonded L-4-hydroxyproline phase with capillaries containing
N-decyl-L-hydroxyproline dynamically coated on a reversed phase [37]. While the chemically bonded phase was found to be suitable for the chiral separation of amino acids and dipeptides, the dynamically coated phase gave the better results for hydroxy acids (Figure 9). A reduction of retention time and improvement of efficiency was obtained by diluting the chemically bonded phase with bare silica to increase the EOF.

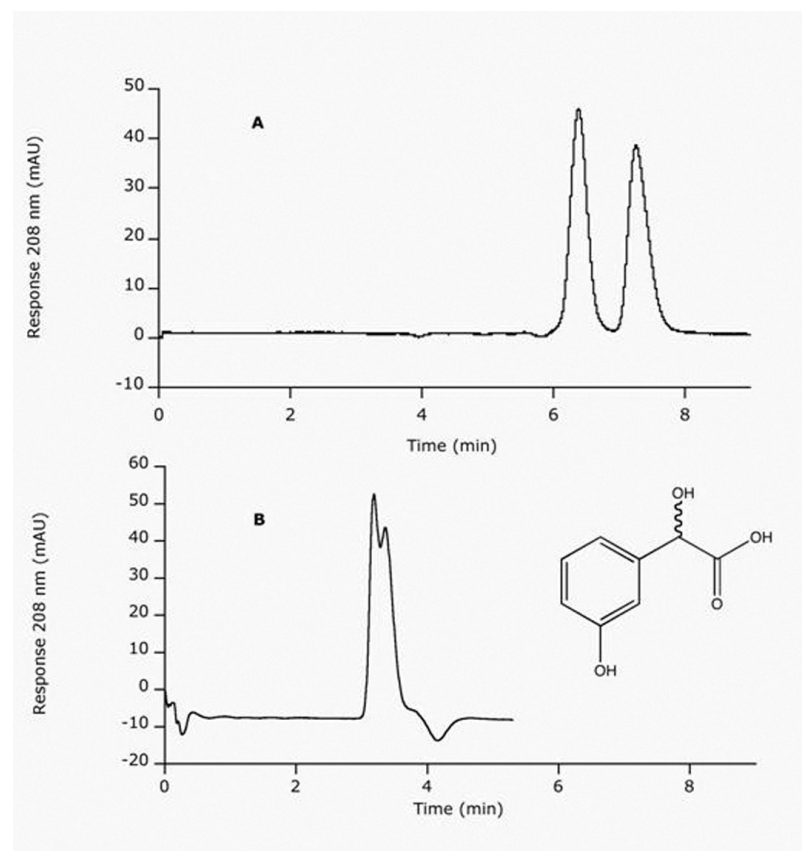

Fig. 9. Enantioseparation of 3-hydroxymandelic acid. Stationary phase: (A) dynamically coated LE-CSP; (B) chemically bonded LE-CSP. Mobile phase: $25 \mathrm{mM}$ ammonium acetate buffer, $0.5 \mathrm{mM} \mathrm{Cu}(\mathrm{II}), \mathrm{pH} 4.5$.

Temperature: $25^{\circ} \mathrm{C}$. Applied voltage: $5 \mathrm{kV}$ to the anode, 12 bar pressure support.

A disadvantage of packed capillaries is the complicated packing procedure whereby the frits have to be prepared by sintering a zone of the silica based packing. To overcome these shortcomings a recent trend is to prepare monolithic phases.

Chen et al. [38, 39] prepared monolithic phases on silica bases by polycondensation of tetramethoxysilane in a sol-gel process. As chiral selectors they used amino acid amides wich were chemically bonded to the monolith. The 
authors resolved dansyl amino acids on these phases. We prepared monolithic phases (continuous beds) by in situ copolymerisation of methacrylamide (monomer), piperazine diacrylamide (crosslinker), vinlysulfonic acid (charge providing agent for generating an EOF) and N-(2-hydroxy-3-allyloxypropyl)-L-4-hydroxyproline (chiral selector) [40]. To fix the polymer in the capillary, the wall was pretreated with $\alpha$-methacryloxypropyltrimethoxysilane which participates in polymerization. Ammonium sulfate was added for acting as a porogen and the polymerization was started by ammonium peroxodisulfate. The advantages of this approach are the ease of preparation and the fact that the capillary can be cut to any desired length. It was demonstrated by means of the chiral separation of phenylalanine that the same capillary can be used for CEC, nano-HPLC and pressure supported CEC. To reduce the separation time, short end injection at the anodic side with a 8 $\mathrm{cm}$ packing and 12 bar pressure support were applied.

Replacing N-(2-hydroxy-3-allyloxypropyl)-L-4-hydroxyproline by the longer-chain $\mathrm{N}$ -(2-hydroxyoctenyl)-L-4-hydroxyproline gave comparable results.

Hydroxy acids are negatively charged and tend to migrate in direction opposite to the EOF. This fact resulted in extremely long separation times. Omitting the negatively charge providing agent vinlysulfonic acid in the monomer mixture was one parameter checked for reducing separation time [41]. More effective was the replacement of vinylsulfonic acid by a positive charge-providing agent, diallyldimethylammonium chloride [42]. Thereby an EOF is generated wich is superimposed to the migration of the hydroxy acids.

An attempt to improve efficiency was the creation of the particle-loaded continuous beds [43]. In this approach a silica based CSP is suspended in an achiral monomer mixture. For ligand-exchange separation we bonded L4-hydroxyproline to $3 \mu \mathrm{m}$ silica and mixed the material with the monomers for polymerization. Figure 10 shows the chiral separation of

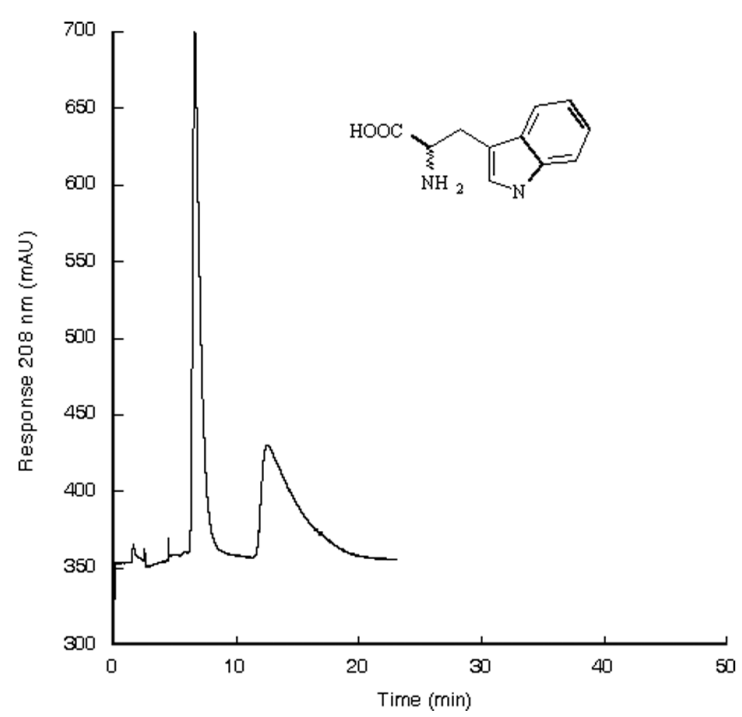

Fig. 10: Chiral separation of tryptophan by particleloaded CEC. Conditions: stationary phase: $15 \mathrm{wt} \% \mathrm{LE}$ chiral silica particles in a CB $(6 \mathrm{~cm} \times 100 \mu \mathrm{m}, 34 \mathrm{~cm}$ entire length), mobile phase: $50 \mathrm{mM}$ phosphate solution, $1 \mathrm{mM} \mathrm{Cu}$ (II) $\mathrm{pH} 4.5$

tryptophan on this particle loaded monolith. The advantage of this simple approach is that any commercially CSP used in HPLC can be incorporated in the polymer.

As an alternative to the use of the methacryl amide polymer backbone, monoliths prepared by a ring opening methathesis polymerization (ROMP). The synthesis is carried out by mixing norborn-2-ene, 1, 4, 4a, 5, 8, 8a-hexahydro-1, 4, 5, 8, exo, endo-dimethanonaphthalene as monomers, propan-2-ol and toluene as porogens, $\mathrm{RuCl}_{2}\left(\mathrm{PCy}_{3}\right)_{2}$ as initiator and silica based particles containing the chiral selector. Comparable results were obtained with this approach. Figure 11 shows the enantioseparation of DOPA [44].

Although only one example using LE has been reported to date, a few milestones on the development of microfluid devices are presented in this chapter. The first microchip system for enantioseparation was developed by Hutt et al. [45]. The authors made use of a CD-MEKC system with $\alpha-C D$ in combination with SDS for the chiral separation of FITC-labeled amino acids using LIF detection. The development of 


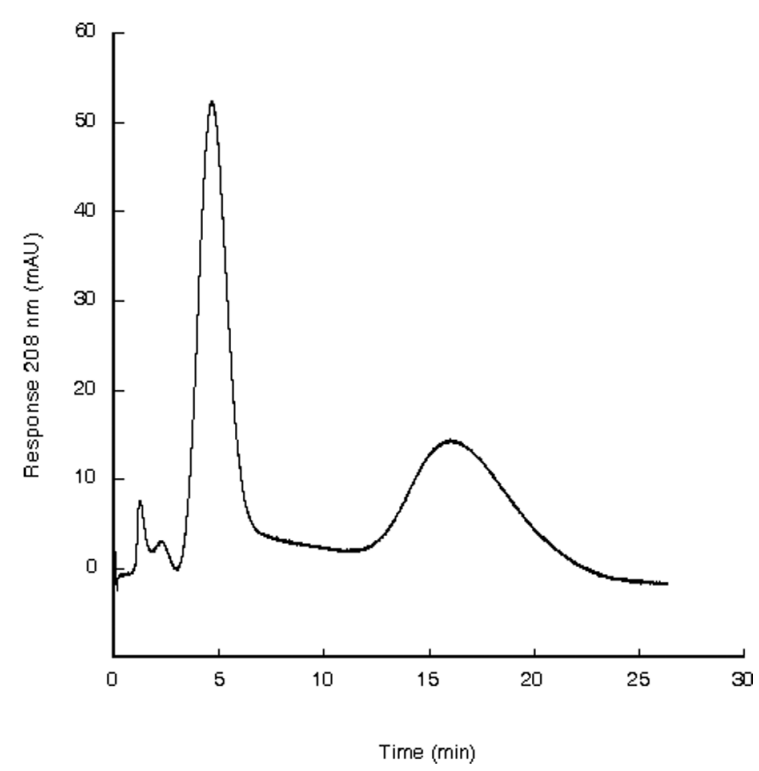

Fig. 11: Enantiomeric separation of DOPA by a ringopening metathesis polymerization (ROMP) particleloaded continuous bed

Conditions: particle-loaded ligand-exchange monolith $(27.5 \mathrm{~cm})$. Mobile phase: $25 \mathrm{mM}$ phosphate solution, $1 \mathrm{mM} \mathrm{Cu}$ (II) $\mathrm{pH}$ 4.5. Inj.: 12 bar $\times 9 \mathrm{~s}, 15 \mathrm{kV}$ and 12 bar pressure support

a microchip CE system in combination with on-chip chemiluminescence detection was reported by Liu et al. [46]. The authors resolved Dns-amino acids by means of HP-ß-CD as chiral selector using the peroxyoxalate-hydrogen peroxide chemiluminescence detection system. Ludwig et al. [47] described the use of a commercially available microchip electrophoresis system (MCE 2010, Shimadzu, Kyoto, Japan) containing a linear imaging UV detection system. In this case the separation can be monitored continuously, since the detection is carried out on the whole separation channel. The fastest separation reported up to now was reported by Piehl et al. [48]. The authors resolved Dns-amino acids within $720 \mathrm{~ms}$ using highly sulfated CDs in a microchip system containing a separation channel of only $7 \mathrm{~mm}$ in length. To date, only one application of LE-CE using microchip technique has been reported [49]. We are currently working on the development of microchip techniques for chiral electrochromatographic separations using the principle of ligand-exchange.

\section{CONCLUSIONS AND FUTURE TRENDS}

The principle of chiral ligand exchange holds a well established position among chiral separation techniques. Although this principle is restricted to chelate complex forming compounds, it offers a wide application spectrum. For amino acid enantiomer separation, it is still the most frequently used technique. Its application ranges from control for racemization in synthesis, enantiomer purity checks over detection of rare $\mathrm{D}$-amino acids in natural samples to the determination of the amino acid enantiomer ratio for age determination in excavations.

Recent trends are miniaturization techniques such as the use of nano-HPLC or microchip devices in CE. In general, electromigration techniques offer a useful alternative to LC, since small amounts of both solvents and analyte are required. Further developments in CEC are to be expected. Especially the use of monolithic phases as a trend to move away from complicated packing procedures is in progress. A promising approach represents the online-coupling of ITP with CZE for sample pretreatment and preconcentration. This is of relevance for the analysis of biological samples in pharmaceutical analysis. To enhance sample throughput, capillary array systems are in development. On-capillary preconcentration by stacking and sweeping techniques will be further contributions for sensitivity enhancement. Since UV detection is not sensitive enough for trace analysis in CE, LIF, MS and electrochemical detection are increasingly used.

\section{REFERENCES}

[1] Davankov, V. A. and Rogozhin, S. V.: Ligand Chromatography as a Novel Method for Investigation of Mixed Complexes - Stereoselective Effects in Alpha-Amino Acid Copper(II) Complexes. J. Chromatogr. A, 60, 284-312 (1971).

[2] Rogozhin, S. V. and Davankov, V. A.: USSR patent 308635, (1968). 
[3] Rogozhin, S. V. and Davankov, V. A.: Dokl. Akad. Nauk., 193, 94 (1970).

[4] Gübitz, G.: Direct Separation of Enantiomers by High-Performance Ligand-Exchange Chromatography on Chemically Bonded Chiral Phases. J. Liq. Chromatogr., 9, 519-535 (1986).

[5] Gübitz, G., Jellenz, W., Löffler, G. and Santi, W.: Chemically Bonded Chiral Stationary Phases for the Separation of Racemates by HPLC. J. High Resol. Chromatogr., 2, 145-146 (1979).

[6] Gübitz, G., Jellenz, W. and Santi, W.: Separation of the Optical Isomers of Amino-Acids by Ligand-Exchange Chromatography Using Chemically Bonded Chiral Phases. J. Chromatogr. A, 203, 377-384 (1981).

[7] Gübitz, G., Juffmann, W. and W., J.: Direct separation of amino acid enantiomers by high performance ligand-exchange chromatography on chemically bonded chiral phases. Chromatographia, 16, 103-106 (1982).

[8] Grobuschek, N., Schmid, M. G., Tuscher, C., Ivanova, M. and Gübitz, G.: Chiral separation of beta-methyl-amino acids by ligand exchange using capillary electrophoresis and HPLC. J. Pharm. Biomed. Anal., 27, 599-605 (2002).

[9] Gübitz, G. and Mihellyes, S.: Resolution of 2-Hydroxydicarboxylic Acid Enantiomers by Ligand-Exchange Chromatography on Chemically Bonded Chiral Phases. J. High. Res. Chrom., 17, 733-734 (1994).

[10] Gübitz, G., Vollmann, B., Cannazza, G. and Schmid, M. G.: Chiral resolution of dipeptides by ligand exchange chromatography on chemically bonded chiral phases. J. Liq. Chromatogr., 19, 2933-2942 (1996).

[11] Gubitz, G. and Juffmann, F.: Resolution of the Enantiomers of Thyroid-Hormones by High-Performance Ligand-Exchange Chromatography Using a Chemically Bonded Chiral Stationary Phase. J. Chromatogr. A, 404, 391-393 (1987).

[12] Gübitz, G., Mihellyes, S., Kobinger, G. and Wutte, A.: New Chemically Bonded Chiral Ligand-Exchange Chromatographic Stationary Phases. J. Chromatogr. A, 666, 91-97 (1994).

[13] Roumeliotis, P., Unger, K. K., Kurganov, A. A. and Davankov, V. A.: High-Performance LigandExchange Chromatography of Alpha-Amino-Acid Enantiomers - Studies on Monomerically Bonded 3-(L-Prolyl)Propyl and 3-(L-Hydroxyprolyl)Propyl Silicas. J. Chromatogr. A, 255, 51-66 (1983).
[14] Davankov, V. A., Navratil, J. D. and Walton, H. F.: Ligand Exchange Chromatography. CRC Press, Inc., Boca Raton, Florida, 1988.

[15] Hyun, M. H., Han, S. C., Lee, C. W. and Lee, Y. K.: Preparation and application of a new ligand exchange chiral stationary phase for the liquid chromatographic resolution of alpha-amino acid enantiomers. J. Chromatogr. A, 950, 55-63 (2002).

[16] Davankov, V. A.: Enantioselective ligand exchange in modern separation techniques. J. Chromatogr. A, 1000, 891-915 (2003).

[17] Davankov, V. A., Bochkov, A. S., Kurganov, A. A., Roumeliotis, P. and Unger, K. K.: Dealing with the Ligand-Exchange Chromatography. 13. Separation of Unmodified Alpha-Amino-Acid Enantiomers by Reversed Phase HPLC. Chromatographia, 13, 677-685 (1980).

[18] Davankov, V. A., Bochkov, A. S. and Belov, Y. P.: Ligand-Exchange Chromatography of Racemates.15. Resolution of Alpha-Amino-Acids on Reversed-Phase Silica-Gels Coated with N-Decyl-L-Histidine. J. Chromatogr. A, 218, 547-551 (1981).

[19] Mohr, S., Kremsmair, C. and Schmid, M. G., in preparation (2010).

[20] Schmid, M. G., Schreiner, K., Reisinger, D. and Gubitz, G.: Fast chiral separation by ligand-exchange HPLC using a dynamically coated monolithic column. J Sep Sci, 29, 1470-1475 (2006).

[21] Hare, P. E. and Gil-Av, E.: Separation of D and L Amino Acids by Liquid Chromatography: Use of Chiral Eluants. Science, 204, 1226-1228 (1979).

[22] Lindner, W., Lepage, J. N., Davies, G., Seitz, D. E. and Karger, B. L.: Reversed-Phase Separation of Optical Isomers of Dns-Amino Acids and Peptides Using Chiral Metal Chelate Additives. J. Chromatogr. A, 185, 323-343 (1979).

[23] Schmid, M. G.: unpublished results.

[24] Gassmann, E., Kuo, J. E. and Zare, R. N.: Electrokinetic Separation of Chiral Compounds. Science, 230, 813-814 (1985).

[25] Gozel, P., Gassmann, E., Michelsen, H. and Zare, R. N.: Electrokinetic Resolution of Amino-Acid Enantiomers with Copper(II) Aspartame Support Electrolyte. Anal. Chem., 59, 44-49 (1987).

[26] Schmid, M. G. and Gübitz, G.: Direct enantiomer separation of underivatized amino acids by capillary zone electrophoresis based on ligand exchange. Enantiomer, 1, 23-27 (1996). 
[27] Chen, Z., Lin, J. M., Uchiyama, K. and Hobo, T. : Reversal behaviors of the enantiomer migration order and the stereo-selectivity of $\mathrm{Cu}$ (II) complex with amino acid enantiomers in ligand exchange-micellar electrokinetic chromatography. Anal. Sci.; 16, 131-137 (2000).

[28] Végvári, Á., Schmid, M. G., Kilár, F. and Gübitz, G.: Chiral separation of alpha-amino acids by ligand-exchange capillary electrophoresis using $\mathrm{N}$-(2-hydroxy-octyl)-L-4-hydroxyproline as a selector. Electrophoresis, 19, 2109-2112 (1998).

[29] Koidl, J., Hödl, H., Schmid, M. G., Pantcheva, S., Pajpanova, T. and Gübitz, G.: Chiral separation of halogenated amino acids by ligand-exchange capillary electrophoresis. Electrophoresis, 26,38783883 (2005).

[30] Schmid, M. G., Laffranchini, M., Dreveny, D. and Gübitz, G.: Chiral separation of sympathomimetics by ligand exchange capillary electrophoresis. Electrophoresis, 20, 2458-246 (1999).

[31] Schmid, M. G., Lecnik, O., Sitte, U. and Gübitz, G.: Application of ligand-exchange capillary electrophorersis to the chiral separation of alpha-hydroxy acids and beta-blockers. J. Chromatogr. A, 875, 307-314 (2000).

[32] Hödl, H., Krainer, A., Holzmüller, K., Koidl, J., Schmid, M. G. and Gübitz, G.: Chiral separation of sympathomimetics and beta-blockers by ligandexchange $\mathrm{CE}$ using $\mathrm{Cu}$ (II) complexes of L-tartaric acid and L-threonine as chiral selectors. Electrophoresis; 28, 2675-2682 (2007).

[33] Mohr, S., Hägele, J. S. and Schmid, M. G.: Enantioseparation of dansylated amino acids using L-phenylalaninamide, L-lysine and L-threonine as chiral selector. Croat. Chim. Acta 2011; in press.

[34] Hödl, H., Schmid, M. G. and Gübitz, G.: Chiral separation of amino acids and glycyl dipeptides by chiral ligand-exchange capillary electrophoresis comparing $\mathrm{Cu}(\mathrm{II}), \mathrm{Co}(\mathrm{II}), \mathrm{Ni}(\mathrm{II})$ and $\mathrm{Zn}$ (II) complexes of three different sugar acids. J Chromatogr $A$, 1204, 210-218 (2008).

[35] Schmid, M. G., Wirnsberger, K., Jira, T., Bunke, A. and Gübitz, G.: Capillary electrophoretic chiral resolution of vicinal diols by complexation with borate and cyclodextrin: Comparative studies on different cyclodextrin derivatives. Chirality, 9, 153-156 (1997).

[36] Jira, T., Bunke, A., Schmid, M. G. and Gübitz, G.: Chiral resolution of diols by capillary electrophoresis using borate-cyclodextrin complexation. $J$. Chromatogr. A, 761, 269-275 (1997).
[37] Pittler, E., Grawatsch, N., Paul, D., Gübitz, G. and Schmid, M. G.: Enantioseparation of amino acids, alpha-hydroxy acids, and dipeptides by ligand-exchange CEC using silica-based chiral stationary phases. Electrophoresis, 30, 2897-2904 (2009).

[38] Chen, Z. and Hobo, T.: Chemically L-phenylalaninamide-modified monolithic silica column prepared by a sol-gel process for enantioseparation of dansyl amino acids by ligand exchange-capillary electrochromatography. Anal. Chem.; 73, 33483357 (2001).

[39] Chen, Z., Niitsuma, M., Uchiyama, K. and Hobo, T.: Comparison of enantioseparations using $\mathrm{Cu}(\mathrm{II})$ complexes with L-amino acid amides as chiral selectors or chiral stationary phases by capillary electrophoresis, capillary electrochromatography and micro liquid chromatography. J. Chromatogr. $A$, 990, 75-82 (2003).

[40] Schmid, M. G., Grobuschek, N., Tuscher, C., Gübitz, G., Végvári, Á., Machtejevas, E., Maruska, A. and Hjertén, S.: Chiral separation of amino acids by ligand-exchange capillary electrochromatography using continuous beds. Electrophoresis, 21, 3141-3144 (2000).

[41] Schmid, M. G., Grobuschek, N., Lecnik, O., Gübitz, G., Végvári, Á. and Hjertén, S.: Enantioseparation of hydroxy acids on easy-to-prepare continuous beds for capillary electrochromatography. Electrophoresis, 22, 2616-2619 (2001).

[42] Lecnik, O., Gübitz, G. and Schmid, M. G.: Role of the charge in continuous beds in the chiral separation of hydroxy acids by ligand-exchange capillary electrochromatography. Electrophoresis, 24, 2983-2985 (2003).

[43] Schmid, M. G., Koidl, J., Wank, P., Kargl, G., Zohrer, H. and Gubitz, G.: Enantioseparation by ligand-exchange using particle-loaded monoliths: capillary-LC versus capillary electrochromatography. J Biochem Biophys Methods, 70, 77-85 (2007).

[44] Schreiner, K.: Enantiomer separation of amino acids and dipeptides by chiral monoliths and HPLC or CEC. Diploma work (2005).

[45] Hutt, L. D., Glavin, D. P., Bada, J. L. and Mathies, R. A.: Microfabricated capillary electrophoresis amino acid chirality analyzer for extraterrestrial exploration. Anal Chem; 71, 4000-4006 (1999).

[46] Liu, B. F., Ozaki, M., Utsumi, Y., Hattori, T. and Terabet, S.: Chemiluminescence detection for a microchip capillary electrophoresis system fabricated in poly(dimethylsiloxane). Anal Chem, 75, 36-41 (2003). 
[47] Ludwig, M., Kohler, F. and Belder, D. High-speed chiral separations on a microchip with UV detection. Electrophoresis; 24, 3233-3238 (2003).

[48] Piehl, N., Ludwig, M. and Belder, D.: Subsecond chiral separations on a microchip. Electrophoresis; 25, 3848-3852 (2004).
[49] Nakajima, H., Kawata, K., Shen, H., Nakagama, T. and Uchiyama, K.: Chiral separation of NBDamino acids by ligand-exchange micro-channel electrophoresis. Anal Sci, 21, 67-71 (2005). 
